\title{
Noteworthy records of Philippine endemic gingers (Zingiberaceae) in the buffer zone of Mt. Hamiguitan Range Wildlife Sanctuary, Davao Oriental, Philippines
}

\author{
Florfe M. Acma ${ }^{1,2}$, Noe P. Mendez ${ }^{1,2 *}$ \\ ${ }^{1}$ Department of Biology, College of Arts and Sciences, Central Mindanao University, University Town, Musuan, 8710 Bukidnon, \\ Philippines \\ ${ }^{2}$ Center for Biodiversity Research and Extension in Mindanao (CEBREM), Central Mindanao University, University Town, Musuan, \\ 8710 Bukidnon, Philippines \\ ${ }^{\star}$ Corresponding author, E-mail: npolomendez@gmail.com
}

\begin{abstract}
Three Philippine endemic gingers, Alpinia rufa C.Presl, Etlingera dalican (Elmer) A.D.Poulsen and Globba campsophylla K.Schum. are reported for the first time in the province of Davao Oriental, specifically in the buffer zone of the Mt. Hamiguitan Range Wildlife Sanctuary, Sitio Tumalite, Barangay La Union, San Isidro, Davao Oriental, Philippines. Full descriptions of these species, phenology, notes on local names, ethno-medicinal usage, availability status, propagation and habitat ecology along with their photographs are provided.
\end{abstract}

Key words: Alpinia rufa, ethno-medicinal uses, Etlingera dalican, Globba campsophylla, native.

Abbreviations: CMUH, Central Mindanao University Herbarium; FMA, Florfe M. Acma; masl, meters above sea level; MHRWS, Mt. Hamiguitan Range Wildlife Sanctuary; Mt., mountain; NPM, Noe P. Mendez.

\section{Introduction}

Zingiberaceae possess unique flowers by having one stamen that develops as petaloid staminodes (Larsen et al. 1999; Poulsen 2006). Members of this family with more than 1500 species in 53 genera are mostly distributed in tropical forests (Lamb et al. 2013). This family also consists of important spices that are mostly aromatic, perennial and rarely epiphytic herbs (Ke et al. 2000), and have attracted people due to their culinary uses, biological and pharmaceutical activities (Pancharoen et al. 2000). Zingiberaceous plants have been widely used as spice agents, traditional medicine and food flavours, and gingers are relatively new as ornamentals or landscape plants (Boonmee et al. 2011; Lamb et al. 2013).

The spread of Zingiberaceae plants that commonly grow as wild species in forests makes this family an interesting subject for studies (Hatarti et al. 2014). In the Philippines, Zingiberaceae is represented by over 100 species distributed in 16 genera (Pelser et al. 2011 onwards). Of these, three species from three genera (Alpinia Roxb., Etlingera Giseke and Globba L.) are described in this paper. Some field studies on Philippine Zingiberaceae were performed by Funakoshi et al. (2005) on Leptosolena C.Presl and Acma (2010) on biosystematics of Amomum Roxb. Some laboratory studies on the Philippine endemic Zingiberaceae species in tribe
Alpinieae were also conducted (see Barbosa et al. 2016; Mendez et al. 2017; Acma, Mendez 2018).

The Mt. Hamiguitan Range Wildlife Sanctuary (MHRWS) was designated as a World Heritage Site in June 2014, ASEAN Heritage Park in November 2015 and also as a Mindanao Long Term Ecological Research Site (Amoroso et al. 2016). This mountain site is characterized by a variety of vegetation types including a unique mossy pygmy forest (Amoroso et al.2010). Thus far, few species of Zingiberaceae have been reported to be present in the area. Only the study of Acma (2010) dealt with the wild gingers of this area, which reported four species. The aim of the present study was to survey species of Zingiberaceae in the buffer zone of the Mt. Hamiguitan Range Wildlife Sanctuary.

\section{Materials and methods}

An intensive survey was done on the taxonomy of Zingiberaceae in the buffer zone and vicinity of the MHRWS, specifically in the Ecopark, Sitio Tumalite, Barangay La Union, San Isidro, Davao Oriental, Philippines. Field survey was done on March 2017 of different populations of ginger species belonging to genera Alpinia, Etlingera and Globba. Representative specimens were collected and herbarium sheets were prepared using the standard taxonomical methods of Rao and Sharma (1990). 
The collected specimens were deposited in the Central Mindanao University Herbarium (CMUH) with proper voucher specimen numbers. Taxonomic identification was carried out using fresh plant samples and collection of flowers in ethanol. Published research literature, taxonomic monographs, protologue (Ridley 1909; Elmer 1915; Elmer 1919) and relevant online e-flora, such as the Co's Digital flora of the Philippines of Pelser et al. (2011 onwards and JSTOR were used for identification of specimens. Morphological examinations showed that the specimens were Alpinia rufa C.Presl, Etlingera dalican (Elmer) A.D.Poulsen and Globba campsophylla K.Schum. which are endemic and native gingers of the Philippines. Detailed taxonomical descriptions and colour photographs of these species are provided here to facilitate its easy identification. The phenology, notes on local names, ethno-medicinal usage, availability status, propagation and habitat ecology of these species are also given.

\section{Taxonomic treatment}

Alpinia rufa C.Presl (Fig. 1)

-Rel. Haenk. 1 (1827) 114, t. 21.

-RM Sm., Edinburgh J. Bot. 47 (1990) 57, Fig. 8-B; -Languas rufa (C.Presl) Merr., EPFP 1 (1922) 234; -Represented by number 11888, Elmer, Todaya (Mt. Apo), Mindanao, September, 1909.

Morphology. Herbaceous plant that reaches a height of $1-2 \mathrm{~m}$ tall. Pseudostems few to several, ascending, recurved towards the top, green, $0.9-1.5 \mathrm{~m}$ long. Rhizomes creeping, brown, $10-15 \mathrm{~mm}$ in diameter. Leaves alternatingly scattered, the basal ones reduced and more scattering and extending to below the middle, the largest ones toward the apex, slightly descending and recurved, tips abruptly otherwise flat, membranous and smooth above. Leaf blade $18-27 \mathrm{~cm}$ long and $6-7 \mathrm{~cm}$ wide, distichous, sessile,

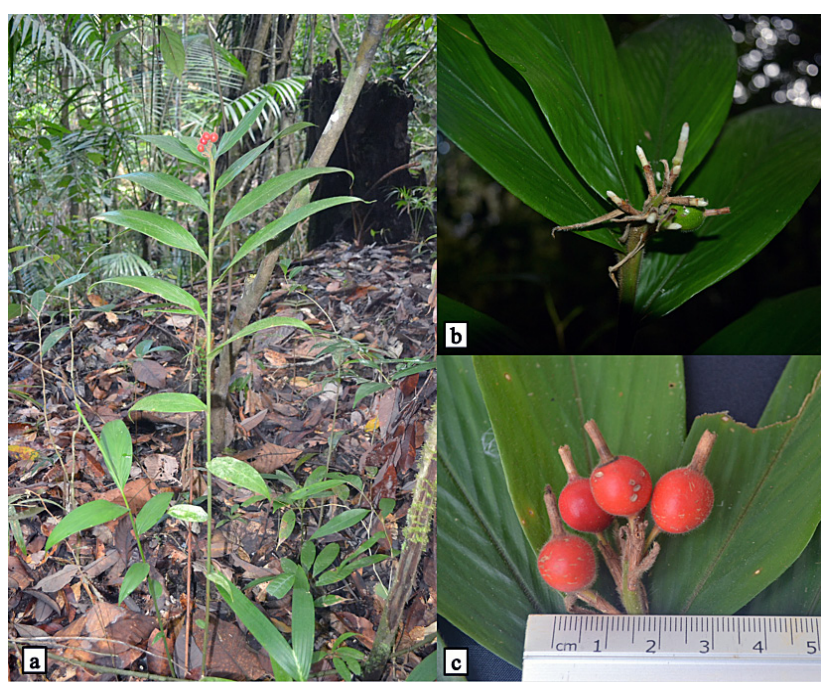

Fig. 1. Alpinia rufa C.Presl.: habit (A), inflorescence with young fruit (B), ripe fruits $(\mathrm{C})$. lanceolate, margin entire to ciliate, base attenuate, apex acuminate, soft pubescent abaxially. Ligule entire, $0.8-1$ $\mathrm{cm}$ long. Inflorescence terminal in the leafy shoots. Flowers small, white, delicate. Fruit globose, pubescent, green when young and bright red when ripe. Seeds numerous, black, surrounded by a white mealy coating.

Phenology. Flowers and fruits were observed throughout the year especially in the months of February to April according to the local researchers (Leonido Clarion, personal communication).

Local names. "Caucos" in the Bagobo dialect (Elmer 1915) and no local name was recorded in the site.

Ethno-medicinal usage. The uses of this plant are not documented.

Availability status. Wild, occasional.

Propagation (ex situ conservation). Rhizomes of $A$. rufa were brought to the Province of Bukidnon for ex situ conservation. However, it was observed that the rhizomes decayed after $2-3$ weeks to 1 month after planting. All three replicates for A. rufa did not survive during ex situ conservation, which might be due to the low elevation where the specimens were planted. Among the three species, A. rufa was the only ginger species that was recorded and collected at high elevation.

Ecology and habitat. Grow as terrestrial herbs near forest trails and associated with rattan, shrubs and vines at an elevation 436 masl. All plant specimens were seen on light slopes with abundant leaf litter on the ground. Elmer (1915) found A. rufa in small delicate tufts in soil with rich moist humus on a densely forested ridge at $1143 \mathrm{~m}$ on the Talon side of the mountain range. He noted that $A$. rufa is a very distinct $Z$ ingiberaceous plant in its subalpine habitat throughout mountainous wooded or forested regions.

Distribution within the Philippines. Luzon: Laguna, Quezon, Camarines, Sorsogon; Polillo, Catanduanes, Panay, Negros, Leyte, Samar, Bucas Grande, Basilan (Elmer 1915; Pelser et al. 2011 onwards), Mindanao: Davao Oriental (present study).

Specimens examined. Philippines, Mindanao, Davao Oriental, Municipality of San Isidro, Barangay La Union, Sitio Tumalite, Mt. Hamiguitan Range Wildlife Sanctuary, terrestrial and found in shaded area, 22 Mar 2017.

Notes. It can be found in flower and fruit at nearly all times of the year. Marcescent scales or sheaths on the branches of the inflorescence or infrutescence are characteristic. The small flowers are white or nearly so and the colour of the mature fruit is a very pleasing goose berry red (Elmer, 1915). Although Alpinia species are the most numerous among the genera of Philippine Zingiberaceae and most species are morphologically similar, A. rufa can be easily recognized and identified if a flower or fruit is available.

\section{Etlingera dalican (Elm.) A.D.Poulsen (Fig. 2)}

-Blumea 48 (2003) 524.

-Amomum dalican (Elmer) Merr., EPFP 1 (1922) 238. 


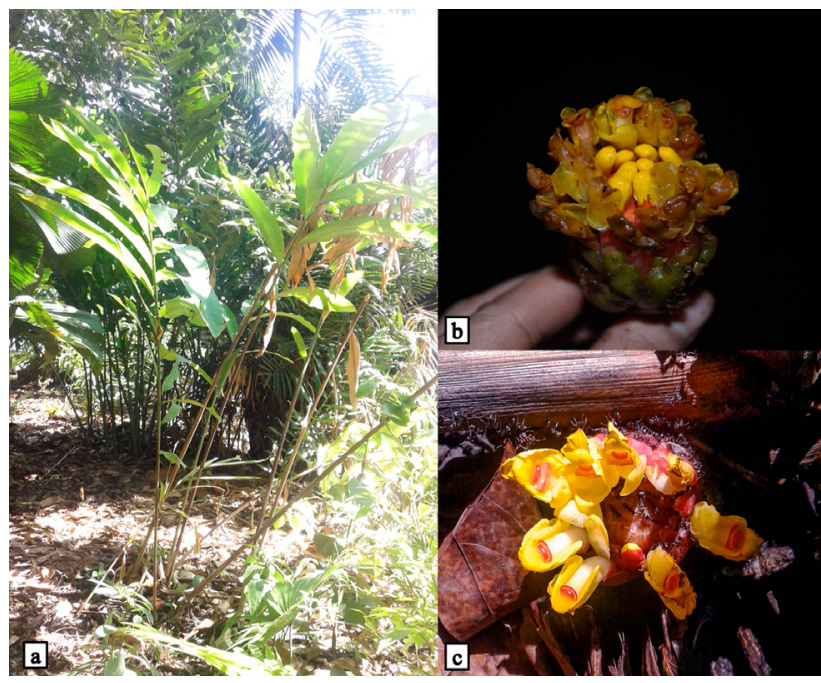

Fig. 2. Etlingera dalican (Elmer) A.D.Poulsen: habit (A), lateral view of the inflorescence $(B)$, top view of the inflorescence $(C)$.

-Hornstedtia dalican Elmer, LPB 8 (1915) 2906. -Type: Elmer 11626 (BISH, GH, K, MO, NY, US, isolecto).

Morphology. A terrestrial herbaceous plant that reaches a height of $1.5-3 \mathrm{~m}$. Pseudostems greenish towards the top and reddish towards the base. Leaves distichous, lanceolate; margin entire to wavy, green, measuring $36 \mathrm{~cm}$ long by 9 $\mathrm{cm}$ wide; apex obtuse with an abrupt acuminate and base acute to rounded; abaxial surface glabrous with reddish color; adaxial surface glabrous with reddish midrib, 15 $18 \mathrm{~cm}$ apart toward the top and much reduced towards the base, the basal part leafless. Ligule $0.4-1 \mathrm{~cm}$ long, entire, oblong, yellowish to brown, hairy. Leaf sheaths glabrous, striate, reddish to brown. Petiole greenish to brownish, short, $0.8-1.2 \mathrm{~cm}$ long, stout, glabrous beneath. Rhizomes long, creeping, branched, pink to reddish to brownish with a diameter of $2-6 \mathrm{~cm}$. Peduncle short, $5-8 \mathrm{~cm}$ long, creamy white. Inflorescence obconic, measuring $8 \times 4 \mathrm{~cm}$ with a truncate top when flowers open, having $10-20$ flowers when fully bloom. Flowers up to $2.5-6 \mathrm{~cm}$ long, enclosed by sterile bracts, subtruncate apex. Pedicels $1-1.5 \mathrm{~cm}$ long. Bracts oblong, tips notched and hairy, pink towards top and white below, largest with size $4 \times 1 \mathrm{~cm}$. Bracteoles tubular, tips hairy, pink towards upper portion while white at base, $3 \mathrm{~cm}$ long. Calyx elongated, fused, tubular, 3-tipped, pink, measuring $3.5 \times 0.3 \mathrm{~mm}$. Corolla lobes oblanceolate, $3 \times 1$ $\mathrm{cm}$, yellow in color. Corolla tube white in color. Pistil up to $4.5 \mathrm{~cm}$ long. Stigma triangular, $0.3 \mathrm{~cm}$ long by $0.1 \mathrm{~cm}$ wide, red to maroon. Style white, slender, $5-6.5 \mathrm{~cm}$ long, broad, located between the anther sacs. Ovary $0.2 \mathrm{~cm}$ long, creamy yellow. Stamens up to $5 \mathrm{~cm}$ long. Anther $6-7.5 \mathrm{~mm}$ long by 0.2. $-0.3 \mathrm{~mm}$ wide, oblong, creamy yellow, position is lower than stigma. Filament whitish, truncate, slender, $4-5 \mathrm{~cm}$ long. Infuctescence and fruits not seen.

Phenology. In all field explorations done by the authors, this species was observed to bear flowers in the period
December to April.

Local names. Called "dalican" in Bagobos (Elmer 1915), "dalikan" in Bukidnon and "tagbak" in Bisaya (Acma 2010) and "bag-ang-bag-ang" by the local people of Davao Oriental referring to the molar-like appearance of the 3 -tooth calyx when the inflorescence is viewed laterally during anthesis. The shape of ripe fruits also resembles a molar tooth (Leonido Clarion and Alfredo Bolante, personal communication).

Ethno-medicinal usage. Acma (2010) reported that the vegetative parts of this species are aromatic, seeds of their ripe fruits are edible and some parts of the plant are boiled to cure fever, as claimed by the local people in Mindanao.

Availability status. Wild, occasional (only one population was found).

Propagation (ex situ conservation and in vitro germination). Acma (2010) successfully propagated this species through ex situ conservation in Bukidnon, Philippines using seeds. Additionally it was observed that the planted specimens bore flowers and fruits every year. Mendez et al. (2017) conducted morphological characterization of pollen and determined its viability, germination and tube growth. Thus, E. dalican can be reproduced using rhizomes for ex situ conservation and pollen for in vitro germination and tube growth.

Ecology and habitat. E. dalican was found on a slope in a shady place where there was no direct sunlight, which supported the earlier observation of Mendez et al. (2017), Acma and Mendez (2018). This species was found along a trail in primary lowland (364 masl) forest with tall trees and ground leaf litter and a fern and grass understory. This species is also water-loving, since it is found in muddy habitat and prefers to grow close to creeks and streams, which was observed also by Mendez et al. (2017).

Distribution within the Philippines. Mindanao: district of Davao (Elmer 1915); Surigao del Sur (Acma 2010) and Davao Oriental (present study).

Specimens examined. Philippines, Mindanao, Davao Oriental, San Isidro, Barangay La Union, Sitio Tumalite, Mt. Hamiguitan Range Wildlife Sanctuary, 22 March 2017, NPM 003-2017.

Other specimens examined. Surigao del Sur, Hinatuan, 7 Feb 2017, FMA 2010 (CMUH 00010859).

Notes. The current record extends the known distribution of this species. E. dalican is easily distinguished from the other Philippine Zingiberaceae species. Inflorescences occur at ground level with yellow flowers forming a truncate top when inflorescences are in full bloom. It closely resembles the Philippine endemic Etlingera pandanicarpa (Elmer) A.D.Poulsen, but is distinguished by having thick and greenish to yellowish green sterile bracts which support the spike. Additionally, the apex of the labellum of E. dalican is almost inward infolded while E. pandanicarpa is wide open and the dorsal corolla lobe is more obvious. E. dalican also resembles another 
non-endemic ginger species - Etlingera fimbriobracteata (K.Schum.) R.M.Sm. and Etlingera burtii A.D.Poulsen. However, E. fimbriobracteata differs from E. dalican in the shape of the labellum (wide open) and colour of the anther crest (bright orange, large and broader), and E. burtii has a shorter labellum that almost covers the deep red stigma and anther crest. Also, the colour of the calyx as shown by Lamb et al. (2013) is yellow towards the top while reddish towards the base, compared to E. dalican which is reddish towards the top and whitish towards the base. Mendez et al. (2017) reported that the flowers of E. dalican do not open at the same time; each flower will open one by one to complete the opening of the whole inflorescence. This species was also observed to be frequently visited by ants and butterflies, which might be their possible pollinators. Further exploration in the Philippines should be continued since the distribution of this species is so far inadequately known.

\section{Globba campsophylla K.Schum. (Fig. 3)}

Engl., Pflanzenreich 20 (1904) 145.

-Ridl., Govt. Lab. Publ. (Philip.) 35 (1906) 83; PJS 4 c (1909) Bot. 159; -Merr., EPFP 1 (1924) 244; - Type: Cuming 1090; Globba brevifolia K.Schum. in Engl., Pflanzenreich 20 (1904) 145; -Ridl., PJS 4 c (1909) Bot. 160; -Merr., EPFP 1 (1924) 244; -Globba parviflora C.Presl var. brevifolia K.Schum. in Engl., Bot. Jahrb. 27 (1899) 330; -Type: Warburg 14066, Luzon: Zambales; -Globba merrillii Ridl., Govt. Lab. Publ. (Philipp.) 35 (1906) 83; -Merr., EPFP 1 (1924) 245; -Type: Merrill 3869, Luzon: Bataan; -Globba gracilis K.Schum. in Engl., Pflanzenreich 20 (1904) 145; -Merr., EPFP 1 (1924) 244; -Type: Warburg 14580 (B, cited by Merr., 1924). -Ridl., PJS 4 c (1909) Bot. 161; -Merr., EPFP 1 (1924) 244; -Type: Merrill 4064. -Globba latifolia.

Morphology. A herbaceous plant measuring up to 45 -

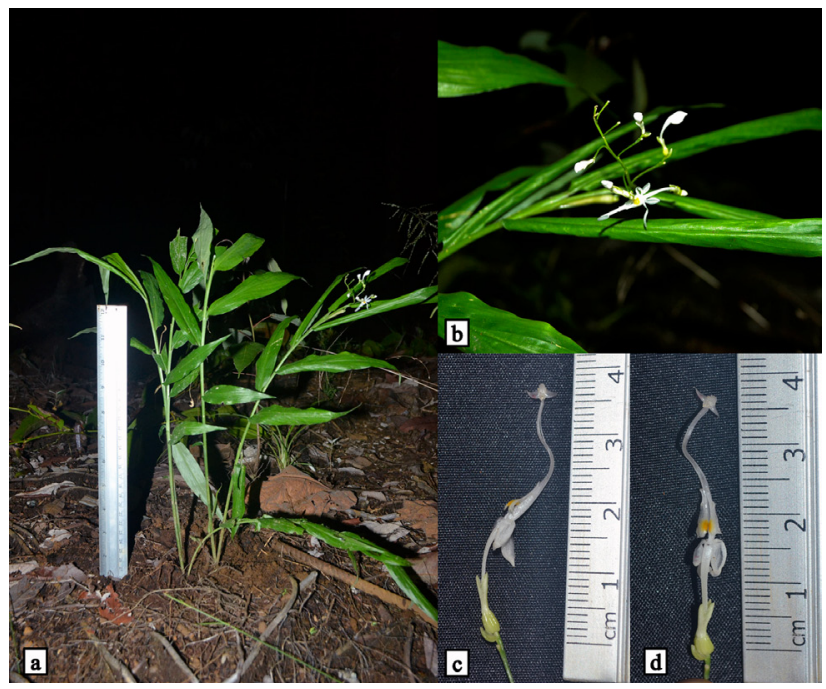

Fig. 3. Globba campsophylla K.Schum.: habit (A), inflorescence (B), lateral view of the flower (C), anterior view of the flower (D).
$70 \mathrm{~m}$ tall, small clumps of 3 - 4 leafy stems. Rhizome short, creeping, fleshy and tufted with fleshy roots measuring up to $1-2 \mathrm{~cm}$ in diameter. Leaves distichous, lanceolate to elliptic to ovate, glabrous, sessile, $23-30 \mathrm{~cm}$ long by 5 - $7 \mathrm{~cm}$ wide; apex acuminate to cuspidate; base rounded, adaxial surface light green to dark green, abaxial surface whitish. Ligule membranous, entire, $0.6 \mathrm{~cm}$ long. Leaf sheaths green towards the apex and red to maroon towards the base. Inflorescence arises terminally from the leafy shoot, lax, erect or pendant. Labellum triangular, 2-lobed. Bracts and bracteoles white, caducous. Calyx white to light green, tubular, 3-tipped/toothed. Filament long, curved, yellow streaked white labellum partially fused to floral tube and the lateral staminodes attached below. Stamen slender with creamy yellow and spur-less anther. Anther appendages present. Epigynous glands narrowly conical with sharp apices. Ovary globose, ovoid, smooth. Fruit 1 $1.3 \mathrm{~cm}$ long, capsules, globose, greenish.

Phenology. Flowering was observed in both wild habitat and ex situ from February to May.

Local names. Local researchers in Mt. Hamiguitan commonly called this species "Luy-a luya-a" referring to the commercially and traditionally used spice ginger, Zingiber officinale Roscoe (Leonido Clarion, personal communication).

Ethno-medicinal usage. The small rhizomes and leaves of this plant are boiled and claimed by the local researchers to cure fever, cough and chills (Leonido Clarion, personal communication).

Availability status. Wild, abundant.

Propagation (ex situ conservation). Rhizomes of this species were brought to Bukidnon for ex situ conservation. After 1 month and 3 weeks from planting of three individuals, the plants bore flowers, flowering period was $1-2$ weeks. Small fruits were also seen in the planted specimens.

Ecology and habitat. Terrestrial in shady dipterocarp forested areas with humid environment, understorey with grasses and Araceae species. Also found near the stream at elevation 236 masl.

Distribution within the Philippines. Luzon: Benguet (Kias province), Nueva Ecija, Bataan (Mount Mariveles), Bulacan, Rizal, Quezon; Visayas: Catanduanes, Panay, Samar; Mindanao: District of Zamboanga, Surigao del Sur, Bukidnon (Lumbres et al. 2010; Pelser et al. 2011 onwards; Blasco et al. 2014) and Davao Oriental (present study).

Specimens examined. Philippines, Mindanao, Davao Oriental, Municipality of San Isidro, Barangay La Unioin, Sitio Tumalite, Mt. Hamiguitan Range Wildlife Sanctuary, terrestrial and found in shaded area, 22 Mar 2017, NPM 002-2017 (CMU 00010869).

Notes. The leafy shoots (if inflorescences are not available) of G. campsophylla closely resemble those of $Z$. officinale; however, the former is abaxially whitish and shorter while the latter is more aromatic and taller. They 
can also be distinguished when inflorescences are available: in the former has a terminal inflorescence while the latter has inflorescences arising from the rhizomes.

\section{Conclusions}

This present paper documents three new records of local distribution of wild Zingiberaceae species. The study results enrich the distribution of $A$. rufa, E. dalican and G. campsophylla, which are endemic to the Philippines. The knowledge of the local researchers on the medicinal uses of the species is of great importance especially in the evaluation of their phytochemical, antioxidant, antiinflammatory properties and for future studies. As botanical exploration progresses, more new species are expected to be added in the flora and sites of the ginger species will be recorded. The documentation of these endemic wild ginger sites adds more value to the said Sanctuary which become as additional flora to Mt. Hamiguitan.

\section{Acknowledgements}

The authors are grateful to the Central Mindanao University for allowing the authors to travel in Mt. Hamiguitan, Davao Oriental, Philippines; Dr. Victor B. Amoroso for the gratuitous permit (GP); Mayor Justina Yu and Sir Ruel D. Colong for the approval to conduct a study on Zingiberaceae at the proposed expansion site of the protected area of MHRWS; Krsytal Mae L. Acero for helping the authors in the preparation of the voucher specimens; and to Tatay Pidoy and Manong Adon for accompanying the authors during the collection of the specimens.

\section{References}

Acma F.M. 2010. Biosystematics of the genus Amomum Roxb. (Family Zingiberaceae) in the Philippines. Doctor of Philosophy (Botany) Dissertation. UP Los Baños.

Acma F.M., Mendez N.P. 2018. Pollen morphology and pollen elemental composition of selected Philippine native gingers in tribe Alpinieae (Alpinioideae: Zingiberaceae). Biol. Forum Int. J. 10: 1-10.

Amoroso V.B., Obsioma L.D., Arlalejo J.B., Aspiras R.A., Capili D.P., Polizon J.J.A., Sumile E.B. 2010. Inventory and conservation of endangered, endemic and economically important flora of Hamiguitan Range, Southern Philippines. Blumea 54: 71-76.

Amoroso V.B., Coritico F.P., Fritsch P.W.2016. Species richness and conservation status of ferns and lycophytes in Mt. Hamiguitan Range Wildlife Santuary, Davao Oriental, Philippines. Philippine J. Sci. 145: 127-137.
Blasco F.A., De Guzman G.Q., Alejandro G.J.D. 2014. A survey of ethnomedicinal plants in Surigao Del Sur Mountain Range, Philippines. Int. J. Pure Appl. Biosci. 2: 166-172.

Boonmee A., Srisomsad C., Chokchaichamnamkit D., Karnchanatat A., Sangvanich P. 2011. A proteomic analysis of Curcuma comosa Roxb. rhizome. Proteome Sci. 9: 43.

Boyce P. 2006. The Gingers of Sarawak. The HSPR Newsletter. Heliconia Society of Puerto Rico. 11: 1-4.

Elmer A.D.E. 1915. Notes and descriptions of Zingiberaceae. Leaflets of Philippine Botany 8: 2885-2919.

Elmer A.D.E. 1919. Zingiberaceae of the Sorsogon Peninsula. Leaflets of Philippine Botany 8: 2963-2995.

Funakoshi H., Kress W.J., Skornickova J., Liu A., Inoue K. 2005. Return from the lost: rediscovery of the presumed extinct Leptosolena (Zingiberaceae) in the Philippines and its phylogenetic placement in gingers. Acta Phytotaxon. Geobot. 56: 41-53.

Hatarti R., Suganda A. Fidrianny I. 2014. Botanical, phytochemical and pharmacological properties of Hedychium (Zingiberaceae) - a review. Proc. Chem. 13: 150-163.

Ke J., Delin W., Larsen K. 2000. Zingiberaceae. Flora of China 24: 322-377.

Lamb A., Gobilik J, Ardiyani M., Poulsen A.D. 2013. A Guide to Gingers of Borneo. Natural History Publications (Borneo), Kota Kinabalu.

Larsen K., Ibrahim H., Khaw S.H. Saw L.G. 1999. Gingers of Peninsular Malaysia and Singapore. Natural History Publications (Borneo), Kota Kinabalu.

Lumbres R.I.C., Palaganas J.A., Micosa S.C., Besic E.D., Laruan K.A., Yun C.W., Lee Y.J. 2010. Geographic information system based floral and faunal assessment of Alapang communal forest of Benguet, Philippines. J. Korean For. Soc. 99: 770-776.

Mendez N.P., Porquis H.C., Sinamban E.B., Acma F.M. 2017. Comparative pollen viability and pollen tube growth of two endemic Philippine Etlingera (Zingiberaceae, Alpinioideae). Philippine J. System. Biol. 11: 1-9.

Pancharoen O., Prawat U., Tuntiwachwuttikul P. 2000. Phytochemistry of the Zingiberaceae. Stud. Nat. Prod. Chem. 23: 797-865.

Pelser P.B., Barcelona J.F., Nickrent D.L. (eds.). 2011. Co's Digital Flora of the Philippines. http://www.philippineplants.org. /Accessed December 6, 2017/

Poulsen A.D. 2006. Etlingera of Borneo. Natural History Publications (Borneo) in association with Royal Botanic Garden Edinburgh. Kota Kinabalu, Sabah. http://www. nhpborneo.com/book. /Accessed November 20, 2014/

Rao R.R., Sharma B.D. 1990. A Manual for Herbarium Collections. BSI, Calcutta.

Ridley H.N. 1909. Zingiberaceae from South Negros. Leaflets Philippine Botany 2: 605-607. 